\title{
Immunoreactive Proteins of Dormant Mycobacterium tuberculosis Cells
}

\author{
K. A. Trutneva ${ }^{a}$, V. G. Avdienko ${ }^{b}$, G. R. Demina ${ }^{a}$, M. O. Shleeva ${ }^{a}$, M. S. Shumkov ${ }^{a}$, \\ E. G. Salina ${ }^{a}$, and A. S. Kaprelyants ${ }^{a, *}$ \\ ${ }^{a}$ Bach Institute of Biochemistry, Fundamentals of Biotechnology Federal Research Center, Russian Academy of Sciences, \\ Moscow, 119071 Russia \\ ${ }^{b}$ Central Tuberculosis Research Institute, Moscow, 107564 Russia \\ *e-mail: arseny@inbi.ras.ru
}

Received August 26, 2020; revised October 20, 2020; accepted November 2, 2020

\begin{abstract}
The protein profile of dormant $M t b$ obtained after the gradual acidification of $M t b$ culture was studied to find antigenic proteins for humans that are expressed by M. tuberculosis (Mtb) cells in vitro under conditions close to the situation of persistence in vivo. According to $2 \mathrm{D}$ electrophoresis, a significant diversity of proteins in dormant cells was found. However, the representation of individual proteins in dormant versus active cells differed substantially. Immunoblotting in different protein fractions of dormant cells revealed ten proteins that are able to bind antibodies in pooled sera of TB patients. Two proteins (Rv2018 and Rv0341) are new immunogenics that were not previously found in other studies. Four proteins (Rv0341, Rv2018, Rv1509, Rv2986) with the maximal structural specificity for $M t b$ due to their unique extended domains were selected for further analysis. These proteins were expressed in $E$. coli cells and studied via enzyme-linked immunosorbent assay (ELISA) for the immunogenicity of individual sera of TB patients and healthy donors. All proteins were found to have the ability to react with individual sera of TB patients. In TB patients, 5-45\% (depending on the particulate protein) have a titer that is higher than the average titers of healthy donors $+\mathrm{SD}$; the most immunogenic was protein Rv2986. Thus, the application of phenotypically changed (dormant) $M t b$ cells makes it possible to identify a specific repertoire of immunodominant proteins that could be used in the construction of polypeptides that are useful for the serodiagnosis of active/latent TB.
\end{abstract}

Keywords: M. tuberculosis, dormant forms, proteome, enzyme-linked immunosorbent assay, serodiagnostics DOI: $10.1134 / \mathrm{S} 0003683821020174$

\section{INTRODUCTION}

Tuberculosis (TB) remains a deadly infectious disease. Each year, about 10 million people fall ill from TB, and 1.5 million die (https://www.who.int/newsroom/fact-sheets/detail/tuberculosis). Although the main epidemiological figures for tuberculosis have stabilized over the past years in the Russian Federation, the epidemic of tuberculosis is still spreading in Russia. In 2019, the Russian Federation was among the twenty countries with the most unfavorable situations for TB (https://www.who.int/news-room/factsheets/detail/tuberculosis). The situation is complicated by the high and growing levels of the detection of TB strains resistant to first-line antibiotics (up to $29 \%$ in 2018) [1]. Another concern regarding the epidemiology of tuberculosis is the high incidence of latent TB infection; an estimated one-quarter of the world's population is latently infected, according to the WHO. Some epidemiologists believe that about $80 \%$ of the Russian population is latently infected with Mycobacterium tuberculosis $(M t b)$. However, the detection of such forms is difficult, since the TB bacteria remain inactive (dormant) in the body during latent infection; these bacteria remain "non-culturable" (NC) and need to be reactivated in order to be cultured.

Despite significant progress in our understanding of the mechanisms underlying latent tuberculosis, many aspects of the long-term persistence of the pathogen in the host body remain a mystery. Apparently, the interaction between the pathogen and the host, in particular, the interaction with the host immune system, plays a significant role in this process [2]. Therefore, it is relevant to reveal a repertoire of immunogenic proteins in dormant forms (DFs) of $M t b$, which differ considerably by their biochemical composition from those detected in active multiplying bacteria [3, 4].

In addition, the identification of immunodominant proteins in Mtb DFs may be of interest for the selection of antigens relevant to TB serodiagnosis. It is noted that such selection is usually based on our knowledge of the production of $M t b$ proteins during active growth, which is very different from the real situation of $M t b$ persistence in the host body. Evidently, successful serodiagnosis requires knowledge of the 
repertoire of $M t b$ antigens expressed in vivo under the influence of stress on the pathogen, e.g., factors of the host immune system. Herein, Mtb DFs, which form in response to the action of stress conditions on bacterial cells in vitro, can represent a unique model of the pathogen state for the study of the Mtb antigen pool in situations that are close to in vivo. Hence, fundamental research regarding stress-related proteomics of mycobacteria is needed.

The goal of this work is to identify immunodominant $M t b$ proteins expressed in an experimental model of stressed cells in vitro with methods of proteomics and immunology.

\section{EXPERIMENTAL}

Formation of dormant $M$. tuberculosis cells. The wild-type $M t b$ strain $\mathrm{H} 37 \mathrm{Rv}$ (obtained from the Central Tuberculosis Research Institute, Moscow) was studied. The strain was initially grown on standard Sauton's medium (g/L): $\mathrm{KH}_{2} \mathrm{PO}_{4}, 0.5 ; \mathrm{MgSO}_{4} \cdot 7 \mathrm{H}_{2} \mathrm{O}, 1.4$; $\mathrm{L}$-asparagine, 4.0; trivalent ferric ammonium citrate, 0.05 ; sodium citrate, $2.0 ; 1 \% \mathrm{ZnSO}_{4}, 0.1 \mathrm{~mL}$, glycerol, $60 \mathrm{~mL} ; \mathrm{pH}=7.0$ (adjusted with $1 \mathrm{M} \mathrm{NaOH}$ ). ADC supplement (bovine serum albumin, glucose, and $\mathrm{NaCl})$ and Twin-80 (0.05\%) were added [5].

Dormant, NC mycobacteria that lost the ability to grow on solid media due to gradual acidification of the medium during the stationary growth phase were obtained as described earlier [3]. The bacteria were grown for 12-15 days in $50 \mathrm{~mL}$ of Sauton's medium with the addition of $0.05 \%$ Twin- 80 and ADC in $100-\mathrm{mL}$ flasks on an orbital shaker (200 rpm). These bacterial cultures were used for passage to a modified Sauton's medium to obtain NC Mtb. The modification of the Sauton's medium included the replacement of Twin- 80 to $0.025 \%$ tyloxapol and ADC to $0.5 \%$ bovine serum albumin, Cohn Analog (Sigma, United States). In contrast to standard Sauton's medium (at a pH of 7.0), the initial $\mathrm{pH}$ values in the modified media were 6.2. The modified Sauton's medium $(200 \mathrm{~mL})$ was placed into a $500-\mathrm{mL}$ flask (three to five flasks per experiment) and incubated at $37^{\circ} \mathrm{C}$ for $40-60$ days with stirring. The $\mathrm{pH}$ of the medium was measured periodically. When the pH reached 6.0-6.2 in the stationary phase, the cultures were transferred to closed, plastic, $50-\mathrm{mL}$ tubes, and 2-(N-morpholino)ethanesulfonic acid (MES) was added to a final concentration of $20 \mathrm{mM}$ to prevent subsequent acidification during long-term storage. Incubation was continued under static conditions at room temperature in the dark for 1 year after seeding.

2D-electrophoresis. Active and dormant cells obtained in four biological repeats of the experiment as described above were combined. The quantity of cells comprised approximately $3.5 \mathrm{~g}$ of wet mass. The bacterial culture was centrifuged at $7000 \mathrm{rpm}$ for $15 \mathrm{~min}$ and washed ten times with a buffer containing the follow- ing (g/L): $\mathrm{NaCl}, 8 ; \mathrm{KCl}, 0.2 ; \mathrm{Na}_{2} \mathrm{HPO}_{4}, 0.24$ (pH 7.4). The cellular pellet was resuspended on ice in a $100-\mathrm{mM}$ HEPES (4-(2-hydroxyethyl)piperazine ethanesulfonic acid) buffer at a $\mathrm{pH}$ of 8.0 containing protease inhibitor cocktail (Sigma, United States) and phenylmethylsulfonyl fluoride (PMSF); the cells were then disrupted with zirconium beads and a FastPrep-24 homogenizer (MP Biomedicals, United States) for 1 min five times for active cells and ten times for dormant cells. The lysate was centrifuged at $13000 \mathrm{~g}$ for $15 \mathrm{~min}$ at $4^{\circ} \mathrm{C}$. The supernatant was divided into membrane (sediment) and cytosolic fractions (supernatant) via ultracentrifugation at $100000 \mathrm{~g}$ for $2 \mathrm{~h}$ based on the principles of sedimentation.

The membrane fraction was washed three times with HEPES buffer via ultracentrifugation and isolated via extraction with sodium dodecyl sulfate detergent ( $2 \%$ sodium dodecyl sulphate (SDS)).

The cytosolic fraction and membrane extract were precipitated with a ReadyPrep 2-D purification kit (BioRad, United States) for the selective precipitation and removal of contaminants, such as detergents, lipids, and phenolic compounds, from the protein samples. This precipitation procedure made it possible to resuspend the protein precipitate in an isoelectrofocusing buffer containing $8 \mathrm{M}$ urea, $2 \mathrm{M}$ thiourea, $10 \mathrm{mM}$ 1,4-dithiotreitol (DTT), $2 \mathrm{mM}$ tris(2-carboxyethyl)phosphine hydrochloride (TCEP), $1 \%$ (wt/vol) CHAPS, $1 \%$ (wt/vol) Triton X-100, $1 \%$ (wt/vol) amidosulfobetaine-14 (ASB), and $0.4 \%$ (vol/vol) ampholytes ( $\mathrm{pH} 3-10)$.

Isoelectric focusing was performed in 5\% polyacrylamide gel (PAAG) (30\% acrylamide/bisacrylamide, $8 \mathrm{M}$ urea, 2\% ampholytes, $\mathrm{pH} \mathrm{3-10}$ and 4-6 ( $1: 4), 1 \%$ CHAPS, $1 \%$ Triton X-100, $0.4 \%$ ASB) in glass tubes with an inner diameter of $2.4 \mathrm{~mm}$ in an isoelectrofocusing cell (Tube Cell 175, BioRad, United States) until it reached 3700 volt-hours.

A total of $100 \mu \mathrm{g}$ of protein from each sample was used for analysis. After isoelectric focusing, the gels were extracted from the glass tubes and fixed in buffer 1 (0.375 M tris- $\mathrm{HCl}, \mathrm{pH} 6.8,2 \mathrm{M}$ urea, $20 \%$ (vol/vol) glycerol, 2\% SDS, 2\% DTT) and buffer $2(0.375 \mathrm{M}$ tris- $\mathrm{HCl}, \mathrm{pH}$ 6.8, $2 \mathrm{M}$ urea, $20 \%$ glycerol, $2 \%$ SDS and $0.01 \%$ bromophenol blue) for $15 \mathrm{~min}$ each. The second direction was carried out as described by O'Farrell [6] with large plates $(20 \times 20 \mathrm{~cm})$ in $12 \%$ PAAG gels with SDS $1.5 \mathrm{~mm}$ thick in standard tris-glycine buffer in PROTEAN II xi cell for vertical electrophoresis (BioRad, United States). The gels were stained with Coomassie CBBG-250 (Roti-Blue Carl Roth, Germany), followed by silver staining (https://www.alphalyse.com/wp-content/uploads/2015/ 09/Silver-stained-protocol.pdf).

The gel images were obtained with Syngene G: BOX Gel \& Blot Imaging Systems (Syngene, United Kingdom). The images of Coomassie stained gels were 
analyzed with the TotalLab TL120 software to calculate the spot density.

Each visible protein spot corresponding to the spot on immunoblot was manually cut from the gel and analyzed as a separate specimen via matrix-assisted laser desorption ionization time-of-flight (MALDI-TOF) analysis. After MALDI-TOF, tandem mass spectrometry (MS/MS) data were used to search the Mascot Protein database (MSDB) for protein identification. The protein functions were taken from the Tuberculist database. Each specimen for 2D analysis was checked twice.

MALDI-TOF protein analysis. Proteins stained with Coomassie brilliant blue on polyacrylamide gels were digested with trypsin as follows. A piece of gel 3$4 \mathrm{~mm}^{3}$ in size was washed twice in $100 \mu \mathrm{L}$ of $40 \%$ acetonitrile solution in $0.1 \mathrm{M} \mathrm{NH}_{4} \mathrm{HCO}_{3}$ for $20 \mathrm{~min}$ at $37^{\circ} \mathrm{C}$ to remove the dye.

Proteins stained with silver on PAAG gels were hydrolyzed as follows. A 3- to 4- $\mathrm{mm}^{3}$ piece of gel was washed twice in $100 \mu \mathrm{L}$ of a mixture containing $30 \mathrm{mM} \mathrm{K}{ }_{3} \mathrm{Fe}(\mathrm{CN})_{6}$ and $100 \mathrm{mM} \mathrm{Na}_{2} \mathrm{~S}_{2} \mathrm{O}_{3}(1: 1)$ for $15 \mathrm{~min}$ to remove the dye. After the liquid phase was removed, it was washed three times with deionized water for $10 \mathrm{~min}$. After the removal of the dye, the gel was washed with $40 \%$ acetonitrile solution in $0.1 \mathrm{M}$ $\mathrm{NH}_{4} \mathrm{HCO}_{3}$ for $20 \mathrm{~min}$.

After the washing solutions were removed, acetonitrile $(100 \mu \mathrm{L})$ was added to dehydrate the gel. After acetonitrile was removed and a piece of the gel was dried, $3.5 \mu \mathrm{L}$ of modified trypsin solution (Promega, United States) in $0.05 \mathrm{M} \mathrm{NH}_{4} \mathrm{HCO}_{3}$ in a concentration of $15 \mathrm{mg} / \mathrm{mL}$ was added. Hydrolysis was performed for $5 \mathrm{~h}$ at $37^{\circ} \mathrm{C} ; 5.25 \mu \mathrm{L}$ of $0.5 \%$ TFA in a $50 \%$ solution of aqueous acetonitrile was added and thoroughly mixed. The solution on the gel was used to obtain the MALDI mass spectra.

The sampels for mass spectrometry were prepared as follows: $1.5 \mu \mathrm{L}$ of the sampel and $0.5 \mu \mathrm{L}$ of a 2,5-dihydroxybenzoic acid solution $(10 \mathrm{mg} / \mathrm{mL}$ in $20 \%$ aqueous acetonitrile, $0.5 \%$ TFA) were mixed on the target, and the resulting mixture was air-dried.

Mass spectra were generated with an Ultraflextreme MALDI-TOF mass spectrometer (Bruker, Germany) equipped with a UV laser $(\mathrm{Nd})$. Measurements were performed in positive ion reflectron mode. The accuracy of the measured monoisotopic mass peaks upon additional calibration after trypsin autolysis was $0.007 \%(70 \mathrm{ppm})$. Spectra were obtained in the mass range of $500-6500 \mathrm{~m} / z$ with the selection of the optimal laser power to achieve the best resolution. Fragmentation spectra were obtained with the tandem MS mode. The mass accuracy measurement of the fragment ions was at least $2 \mathrm{Da}$.

The proteins were identified with the Blast tool of the National Center for Biotechnology Information (NCBI). Candidate peptide sequences were selected from the proteins of other organisms based on the assumed amino-acid sequences for the fragmentation spectra of individual peptides. The mass spectra were processed with the FlexAnalysis 3.3 software (Bruker Daltonics, Germany).

Immunoblotting. Immunoblotting was performed after the proteins were transferred from the gels to the PVDF membrane in a Protean chamber (Bio-Rad, United States). The reaction of the primary antibodies was carried out in a solution containing antibodies from patients or healthy people (dilution $1: 300$ ), $5 \%$ bovine serum albumin, and $0.1 \mathrm{M} \mathrm{NaCl}$ for $1 \mathrm{~h}$. The membranes were washed with the same solution without antibodies three times for $10 \mathrm{~min}$. Hybridization with secondary antibodies was performed with peroxidase-conjugated, goat, antihuman antibody (Sigma-Aldrich, United States) diluted in a ratio of 1 : 20000. After secondary antibodies were washed off, the spots were visualized with BCIP (5-bromo-4-chloro-3indolyl phosphate) and NBT (nitro blue tetrazolium chloride) (Sigma-Aldrich, United States) according to the manufacturer's recommendations.

Preparation of recombinant proteins. The genes encoding Rv0341, Rv2018, Rv1509, Rv2986, Rv0432, and Rv3676 proteins were cloned from the genomic DNA of the M. tuberculosis H37Rv strain with the primers F 5'-GGCACGcatatgACCTCGCTTATCG-3' (small letters indicate NdeI restrictase recognition site) and $\mathrm{R}$ 5'-GCGTAggatccAGATCACGGTATGC-3' (BamHI site is indicated) for the Rv0341 gene; F 5'GTGAATcatatgGCTGGCGACC-3' (NdeI site is indicated) and R 5'-GctcgagGATTCCGATCAGGCT-3' (Xhol site is indicated) for the Rv2018 gene; F 5'-catatgGTGTTTGCGTTGAGTAATAATCTG-3' (NdeI site is indicated) and $\mathrm{R} 5^{\prime}$-ggatccTTACCTCTTCGTTAGCCGCAC-3' (BamHI site is indicated) for the Rv1509 gene, F 5'-ATCcatatgATGAACAAAGCAGAGCTCATT-3' (NdeI site is indicated) and R 5'-CATggatccCTATTTGCGACCCCGCCGAGC-3' (BamHI site is indicated) for the Rv2986 gene; F 5'-ATCggatccATGCCAAAGCCCGCCGATCAC-3' (BamHI is indicated) and R 5'-CATTaagcttGCCGGAACCAATGACACCGCA-3' (HindIII is indicated) for the Rv0432 gene; F 5'-ATCgaattcGTGGACGAGATCCTGGCCAGG-3' (EcoRI is indicated) and R 5'-CATTaagcttCCTCGCTCGGCGGGCCAGTCT-3' (HindIII is indicated) for the Rv3676 gene.

The PCR products of the Rv0341 and Rv1509 genes were ligated to the pGEM-T easy intermediate vector (Promega, United States) and then transferred to the pET19b final plasmid. The coding part of the Rv2018 and Rv2986 genes was cloned directly into the pET19b vector without intermediate steps. The Rv0432 and Rv3676 genes were cloned in the pET23a vector. The constructs were transformed into an expression strain of $E$. coli BL21DE3. The expression of recombinant proteins from the plasmids led to protein synthesis with a polyhistidine tag $(10 \mathrm{His})$ at the 
$\mathrm{N}$-end of the polypeptide (pET19b vector) and with a polyhistidine tag (6 His) at the $\mathrm{C}$-end of the polypeptide (pET23a vector). Both intermediate and final genetic constructs were verified via PCR and sequencing.

For each protein, the isolation and purification conditions were optimized via metallo-chelate chromatography under denaturing conditions. To obtain protein, an individual colony was inoculated into $50 \mathrm{~mL}$ of meat peptone broth (MPB) containing $100 \mu \mathrm{g} / \mathrm{mL}$ of ampicillin. The culture was incubated overnight with stirring $(220 \mathrm{rpm})$ at $37^{\circ} \mathrm{C}$. Afterwards, $200 \mathrm{~mL}$ of MPB medium (two to four flasks with $200 \mathrm{~mL}$ of the medium) containing $100 \mu \mathrm{g} / \mathrm{mL}$ of ampicillin was inoculated with $1 \%$ of the night culture; the expression inducer isopropyl- $\beta$-D-thiogalactoside (IPTG, $1 \mathrm{mM}$ ) was added when the optical density of the culture reached $\mathrm{OD}_{600}$ 0.5-0.6. Subsequent incubation was performed with stirring at $37^{\circ} \mathrm{C}$ or at room temperature (cold induction) for 4-5 h. At a low level of protein expression, induction was carried out overnight. Cells were collected via centrifugation at $4000 \mathrm{~g}$ for $15 \mathrm{~min}$ and resuspended in $5 \mathrm{~mL}$ of a buffer containing $5 \mathrm{mM}$ imidazole, $0.5 \mathrm{M} \mathrm{NaCl}, 20 \mathrm{mM}$ tris- $\mathrm{HCl}$, pH 8.0 (buffer 1x BB), in the presence of $8 \mathrm{M}$ urea. The cell biomass was stored at $-20^{\circ} \mathrm{C}$ for $2-4$ weeks.

DNase (5 units) and RNase ( $5 \mu \mathrm{g}$ ) were added to the thawed cell biomass in the presence of $\mathrm{Mg}^{2+}$ $(5 \mathrm{mM})$ and $1 \mathrm{x} \mathrm{BB}, \mathrm{pH} 8.0(1 \times \mathrm{BB}, \mathrm{pH} 9.0$ was added to the recombinant Rv1509 protein). The cell biomass was disrupted with an ultrasonic disintegrator (three to five times for $1 \mathrm{~min}$ ) and centrifuged at $10000 \mathrm{~g}$ twice for $30 \mathrm{~min}$ at $4^{\circ} \mathrm{C}$. The supernatant was loaded onto a column with $\mathrm{Ni}^{2+}$-NTA-sepharose $6 \mathrm{~B}$ equilibrated with $1 \times \mathrm{BB}$. After the specimen was loaded, the column was washed with 10 volumes of $1 \times \mathrm{BB}$.

The protein was obtained in two stages. In stage 1 , the urea concentration was reduced from $8.0 \mathrm{M}$ to 0 (urea gradient) over $40 \mathrm{~min}$. In stage 2 , the protein was eluted with 5-500 $\mathrm{mM}$ imidazole (in steps) for $1 \mathrm{~h} 20 \mathrm{~min}$.

Each recombinant protein was dialyzed with an appropriate buffer. The Rv0341 protein was dialyzed with a buffer containing $10 \mathrm{mM} \mathrm{Na} \mathrm{HPO}_{4}, 5 \mathrm{mM}$ $\mathrm{NaCl}, \mathrm{pH}$ 8.0. The $\mathrm{Rv} 1509$ protein was dialyzed with a buffer containing $25 \mathrm{mM}$ Tris- $\mathrm{HCl}, 250 \mathrm{mM} \mathrm{NaCl}$, $\mathrm{pH}$ 9.0. The Rv2018 protein was dialyzed with a buffer containing $20 \mathrm{mM}$ Tris- $\mathrm{HCl}, 200 \mathrm{mM} \mathrm{NaCl}$, pH8.0. The Rv2986, Rv0432, and Rv3676 proteins were dialyzed with a buffer containing $40 \mathrm{mM}$ Tris- $\mathrm{HCl}$, $150 \mathrm{mM} \mathrm{NaCl}, \mathrm{pH} 8.0$. The proteins were dialyzed twice at $4^{\circ} \mathrm{C}$. The proteins were filtered through Millex-GV and Millipore $0.22 \mu \mathrm{m}$ (Sartorius, Germany) and stored at $4^{\circ} \mathrm{C}$.

The protein concentrations were measured with the Flores method [7] and/or a spectrophotometer (BioDrop, Germany) according to the absorption ratio at 280 and $260 \mathrm{~nm}$ with allowance for the molar extinction coefficient.
The purity of recombinant proteins was evaluated via $12 \%$ PAAG electrophoresis and immunoblotting with specific anti-His antibodies and confirmed via MALDI.

Measurement of the protein concentration with the Flores method. A dye solution $(0.9 \mathrm{~mL}, 0.0075 \%$ bromophenol blue solution, $15 \%$ ethanol, and $2.5 \%$ acetic acid) was added to $0.1 \mathrm{~mL}$ of the analyzed protein solution. The optical density was measured via spectrophotometry at $610 \mathrm{~nm}$. Bovine Serum Albumin (BSA) was used to construct the calibration curve. Each sample was analyzed in three repeats.

Determination of the immunoglobulin concentration in blood serum with ELISA. Sorption of the antigen was performed in the wells of a Costar 96-well plate (United States) with a high binding surface overnight at $4^{\circ} \mathrm{C}$ from $100 \mu \mathrm{L}$ of solution with a concentration of $1.0 \mu \mathrm{g} / \mathrm{mL}$ in a $10 \mathrm{mM}$ phosphate buffer, $\mathrm{pH} 7.4$, with $0.17 \mathrm{M} \mathrm{NaCl}$ (FBS). The well plates were washed four times with a phosphate buffer containing $0.05 \%$ twin20 (FBS-T); $100 \mu \mathrm{L}$ of sera diluted with FBS-T at a starting dilution of $1: 50$ and standards of affinity isolated human anti-TB antibodies (0 to $1000 \mu \mathrm{g} / \mathrm{mL}$ ) were then added to the wells and incubated for $30 \mathrm{~min}$ at $37^{\circ} \mathrm{C}$. The well plate was washed three times; $100 \mu \mathrm{L}$ of a solution of monoclonal antihuman IgG-peroxidase labeled antibodies in FBS-T $(1: 1000)$ were added and incubated for $30 \mathrm{~min}$ at $37^{\circ} \mathrm{C}$. After three washings of the well plate, the enzyme immunoassay reaction was assessed in each well. For this, $100 \mu \mathrm{L}$ of $50 \mathrm{mM}$ citrate-acetate buffer, $\mathrm{pH} 5.2$, with $0.035 \%$ 3,3',5,5'-tetramethylbenzidine, and $0.01 \% \quad \mathrm{H}_{2} \mathrm{O}_{2}$, were added to the wells and incubated for $15 \mathrm{~min}$ at room temperature; the reaction was stopped with $1.0 \mathrm{M} \mathrm{H}_{2} \mathrm{SO}_{4}$, and the OP was measured at $450 \mathrm{~nm}$. The concentration of the bound immunoglobulins was estimated with a calibration curve constructed based on human anti-TB antibody standards.

\section{RESULTS AND DISCUSSION}

To detect immunoreactive proteins in $M t b$ cells in a state close to in vivo conditions, we used dormant $M t b$ cells that formed during long-term cultivation with gradual acidification of the culture medium in the poststationary stage [3]. It is known that acidification of the medium is a main factor limiting the growth of M. tuberculosis pathogens in macrophages [8]. Cytosolic and membrane fraction proteins were extracted from $M$. tuberculosis cells obtained during acidification of culture medium, as well as from active multiplying $M t b$ cells. The protein profiles were obtained via 2D electrophoresis [4]. Despite the long-term storage of dormant cells without division, the proteome of such cells retained a large quantity of proteins, but individual proteins differed from the proteome of active cells. Protein stability may be associated with the presence of a substantial number of enzymes 
Table 1. Pool of proteins that exert the ability to bind immunoglobulins in pooled sera of TB patients*

\begin{tabular}{|c|c|c|c|}
\hline Type of M. tuberculosis cells & Protein product & Gene & Rv number \\
\hline Active $\backslash$ dormant $* *$ & Malate synthase $\mathrm{G}$ & $g l c B$ & Rv1837c \\
\hline Active $\backslash$ dormant* & Probable aconitate & Acn & Rv1475c \\
\hline Active** & Universal stress protein TB31.7 & TB31.7 & Rv2623 \\
\hline Active** & Probable S-adenosylmethionine-dependent methyltransferase & Rv0731c & Rv0731c \\
\hline Active $^{* *}$ & Protein Wag31 of the Diviva family & wag31 & Rv2145c \\
\hline Active** & DNA-dependent RNA polymerase ( $\alpha$ subunit) & rроA & Rv3457c \\
\hline Active** & Secreted L-alanine dehydrogenase & ald & $\operatorname{Rv} 2780$ \\
\hline Active $^{* *}$ & Transcription regulatory protein Mox $\mathrm{R} 1$ & $\operatorname{mox} R 1$ & Rv1479 \\
\hline Active** & LIpase $\backslash$ esterase LipN & $\operatorname{lip} N$ & Rv2970c \\
\hline Active $^{* *}$ & Trigger factor (TF) & tig & Rv2462c \\
\hline Active** & Conserved protein & Rv0831c & Rv0831c \\
\hline Active** & Enolase Eno & eno & Rv1023 \\
\hline Active $* *$ & Conserved protein & fhaA & Rv0020c \\
\hline Active** & $\beta$ - ketoacyl-ACP synthase & kas $B$ & Rv2246 \\
\hline Active** & Conserved protein & $35 k d \_a g$ & Rv2744c \\
\hline Active** & Electron-transferring-flavoprotein & fix $B$ & $\operatorname{Rv} 3028 c$ \\
\hline Active** & Transcription antitermination protein & nus $G$ & Rv0639 \\
\hline Active** & Thioredoxin & Rv1324 & Rv1324 \\
\hline Active** & Conserved protein & $\operatorname{Rv} 3075 c$ & Rv3075c \\
\hline Dormant** & Conserved protein & Rv2018 & Rv2018 \\
\hline Dormant** & Aconitase & acn & Rv1475c \\
\hline Dormant $* * *$ & Chaperone GroEL & groEL1 & $\operatorname{Rv} 3417 \mathrm{c}$ \\
\hline Dormant*** & Chaperone DnaK (HSP70) & $d n a K$ & Rv0350 \\
\hline Dormant** & Catalase peroxidase KatG & katG & Rv1908c \\
\hline Dormant** & Methyonine synthase & metE & Rv1133c \\
\hline Dormant $* * *$ & Isoniazid-induced protein IniB & iniB & Rv0341 \\
\hline
\end{tabular}

* Immunoreactive proteins in the proteome of active M. tuberculosis (10 days of culture growth) and in the proteome of dormant tuberculosis pathogen (12 months of storage of the culture), which were found with the use of pooled sera of 10 TB patients, are shown.

** Proteins of the cytoplasmic fraction.

*** Proteins of the membrane fraction.

involved in protection against oxidative stress, as well as chaperones. The proteome of dormant $M t b$ cells included enzymes involved in specific metabolic pathways that may provide low-level metabolism, or these proteins may be stored for use during reactivation prior to the upregulation of biosynthetic processes [4].

Immunoreactive proteins in stressed $M t b$ cells were detected via immunoblotting of the proteins (active and dormant mycobacteria) obtained after 2D electrophoresis. The isolated immunoglobulins from the pooled serum of TB patients were used as primary antibodies. Incubation with secondary antibodies led to the appearance of stained spots. The corresponding protein spots on the original gel were cut out and identified via MALDI-TOF analysis. As a result, nine proteins were detected in dormant cells, and 21 were found in active cells (Table 1). It is notable that these proteins differed in active and dormant cells, except for three proteins, Rv1475c, Rv3804c, Rv1886c.

Sequence alignment of immunoreactive proteins from dormant $M t b$ to protein sequences of other bacteria with the BLAST tool made it possible to rank these proteins based on their similarity with proteins of other bacteria, except for the members of the M. tuberculosis complex (score parameter, Table 2). The three proteins with the lowest score value, i.e., possessing the highest structural specificity for $M t b$ due to the presence of extended domains unique to $M t b$, were subsequently studied in more detail. The corresponding genes were cloned to obtain recombinant proteins (Rv0341 is isoniazid-induced protein IniB; Rv1509 is a protein with unknown function; Rv2018 is an antitoxin) in the form of His-tag proteins based on the pET19b expression vector system (Novagen, India). The recombinant proteins were able to bind specific 
Table 2. Structural homology of immunodominant proteins found in dormant M. tuberculosis cells

\begin{tabular}{l|l|l|c|c|c}
\hline Cellular fraction & \multicolumn{1}{|c|}{ Protein } & \multicolumn{1}{|c|}{ Gene } & $\begin{array}{c}\text { Molecular } \\
\text { mass }\end{array}$ & M. tuberculosis complex** & $\begin{array}{c}\text { Other bacteria } \\
\text { (score) }\end{array}$ \\
\hline Cytoplasm & Catalase peroxidase KatG & Rv1908c & 80572.8 & + & 1311 \\
\hline Cytoplasm & Malate synthase G & Rv1837c & 80403 & + & 1394 \\
\hline Cytoplasm & Aconitase & Rv1475c & & - & 1741 \\
\hline Cytoplasm & Methionine synthase & Rv1133c & 81549.5 & + & 1384 \\
\hline Membranes & Chaperone DnaK & Rv0350 & 66830.9 & + & 1258 \\
\hline Membranes & Chaperone GroEL1 & Rv3417c & 55877.5 & + & 914 \\
\hline Cytoplasm & Conserved protein & $\mathbf{R v 2 0 1 8}$ & $\mathbf{2 6 0 3 4 . 5}$ & Except for M. microtti & $\mathbf{4 3 3}$ \\
\hline sds- membranes & Isoniazid-induced protein IniB & $\mathbf{R v 0 3 4 1}$ & $\mathbf{4 3 9 2 1 . 2}$ & + & $\mathbf{2 0 6}$ \\
\hline sds- membranes & Hypothetical protein & $\mathbf{R v 1 5 0 9}$ & $\mathbf{3 3 0 2 3 . 4}$ & $\begin{array}{c}\text { Only in } \text { M. } \text { tuberculosis } \\
\text { and } \text { M. canetti }\end{array}$ & $\mathbf{4 9 2}$ \\
\hline Cytoplasm & HU homolog HupB & $\mathbf{R v 2 9 8 6 c}$ & $\mathbf{2 2 1 8 7 . 3}$ & + & $\mathbf{2 3 8}$ \\
\hline
\end{tabular}

* The score parameter estimates the sequence coverage and amino-acid sequence similarity in a homologous protein in comparison to the studied $M t b$ protein. High score values indicate a higher sequence similarity. The maximum score values are shown. The proteins with the minimal score value are in bold.

** +/- presence or absence of a homolog for a given protein in all members of the M. tuberculosis complex.

anti-His-tag antibodies during $12 \%$ PAAG electrophoresis and immunoblotting (Fig. 1). Their correspondence to the original proteins was confirmed via MALDI-TOF (not shown).

The recombinant proteins were tested via immunoblotting for their ability to bind antibodies from the sera of TB patients. Immunoglobulins isolated via affinity chromatography from the pooled sera of $12 \mathrm{~TB}$ patients were used as primary antibodies. It was found that the best results were observed if the lipoproteins were preliminary precipitated from serum with dextran sulfate in the presence of calcium ions. The secondary antibodies were phosphatase-conjugated, antihuman antibody or peroxidase conjugated protein $\mathrm{G}$. Incubation led to the appearance of stained bands corresponding to protein spots on the original gel. The immunoreactivity of these recombinant proteins was checked with the use of two additional panels of pooled sera from TB patients. In immunoblotting, all three proteins were capable of binding serum antibodies (Fig. 2).

Since it was possible that not all proteins (especially hydrophobic or oligomeric ones) could be detected via 2D electrophoresis, 1D SDS PAAG gel electrophoresis of proteins was used to separate the proteins of dormant cells. Immunoblotting of the proteins after this separation revealed an immunoreactive band with a high activity in the region of $20 \mathrm{kDa}$. In MALDI-TOF, three proteins were revealed in the immunoreactive area: Rv2986c, hupB (a DNA-binding protein of the HU family); Rv0432, sodC (periplasmic copper- and zinc-cofactored superoxide dismutase); Rv3676, crp, (a transcriptional regulator protein that belongs to $\mathrm{Crp} / \mathrm{Fnr}$ protein family). To identify an immunoreactive protein, all three genes were cloned in $E$. coli cells, and the corresponding proteins were obtained as recombinant proteins in the pET vector system (pET19в and pET23a). The obtained individual proteins were subjected to denaturing PAAG electrophoresis, and immunoblotting with pooled sera from TB patients was performed. It was found that the Rv2986c protein was the only protein capable of binding serum immunoglobulins (Fig. 3). This protein was studied in subsequent experiments.

The obtained four recombinant proteins were used to evaluate the presence of antibodies in individual sera of TB patients and healthy donors via ELISA.

In total, four series of experiments were conducted (one for each protein). In each experiment, 42 sera from TB patients and 42 sera from healthy donors were used. The data revealed that all four recombinant antigens were recognized by the sera of TB patients (Fig. 4). However, only $5-45 \%$ of patients (for different antigens) had immunoglobulin concentrations that exceeded the average values for healthy donors. The maximal elevation was shown for the Rv2986 protein concentration. At the same time, antibodies at concentrations exceeding the same average value were also detected in the sera of $2-14 \%$ of healthy donors.

Two of the studied proteins (Rv2018 and Rv0341) are novel and had not been previously described in the literature. The Rv2018 protein was similar to an antitoxin from the VapB family, which is found in G/Crich actinobacteria, including mycobacteria. It is thought that the toxin-antitoxin systems are essential for the entry of a bacterial population to a dormant state [9]. Based on BLAST, the protein encoded by the Rv0341 gene (isoniazid inducible gene protein, IniB) 
(a)

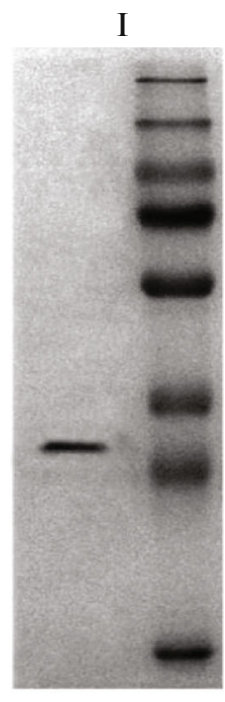

Rv1509 M

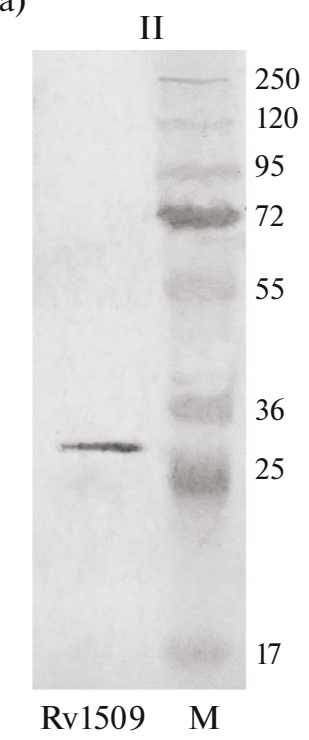

(c)

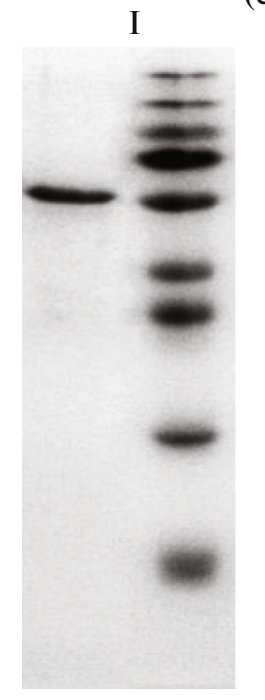

Rv0341 M

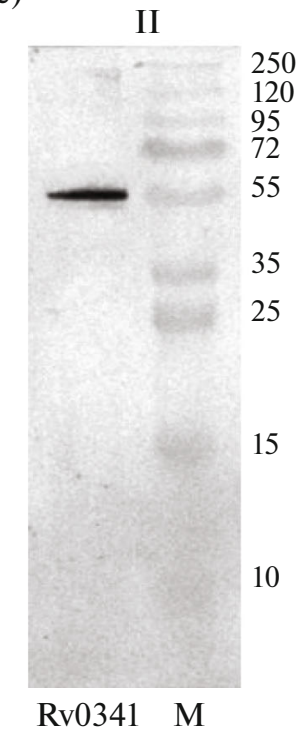

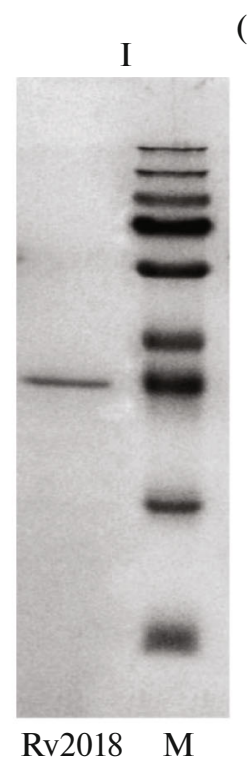

(b)

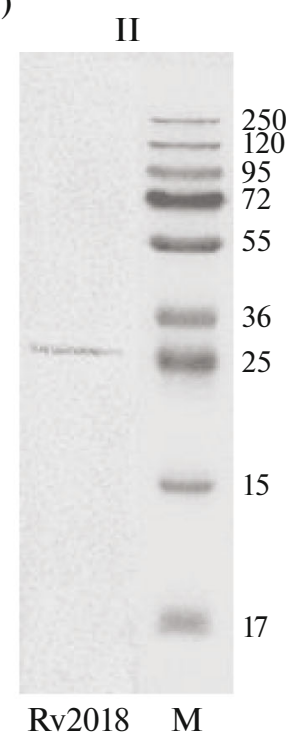

(d)

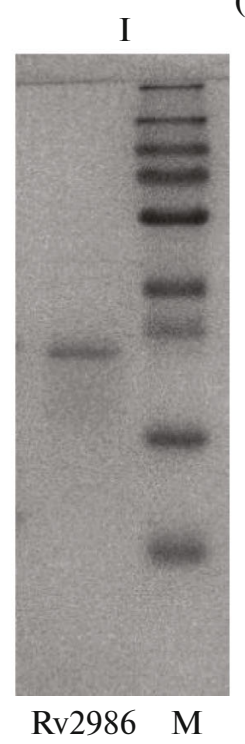

II

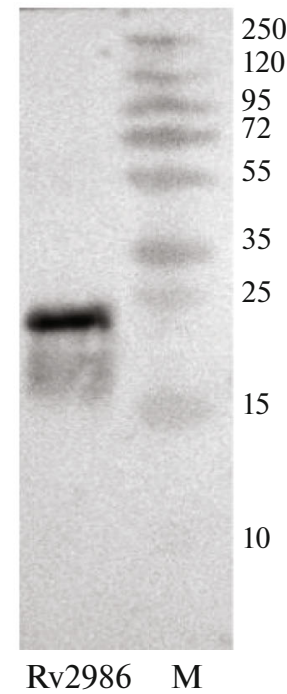

Fig. 1. SDS-electrophoresis in 12\% PAAG (I) of recombinant proteins: Rv1509 (a), Rv2018 (b), Rv0341 (c), Rv2986 (d) and the corresponding immunoblot (II) with specific anti-His-tag antibodies.

is revealed exclusively in mycobacteria and occurs within large complexes $(680 \mathrm{kDa}$ or larger) in the membrane extract of dormant $M$. tuberculosis cells. These complexes decay to a monomeric form in an early reactivation stage of dormant mycobacteria, and large Rv0341 protein complexes disappear in the logarithmic phase. The IniB protein colocalizes with nucleic acids in membrane extracts of dormant mycobacteria [10]. IniB is found to be overexpressed when macrophages are infected with $M t b$ cells. Fragments of the IniB protein bind well to the Major Histocompatibility Complex (MHC) on class 1 and 2 lymphocytes, and, hence, IniB appears to be involved in the cellular immunoresponse [11]. According to a recent publica- tion, IniB protein demonstrates good protective efficacy against TB infection [12]. However, IniB protein was not previously described as possessing the ability to bind antibodies, and it was not included in the list of immunogenic proteins obtained during studies of the total immunoproteome from active $M t b$ cells in publications in 2010-2020 [13-15]. The protein encoded by the Rv2986c gene is a DNA-binding protein and is a histone-like protein (HupB, HU-homo$\log$ ). Its expression is increased both in the stationary phase of $M t b$ growth and in a hypometabolic state [16-18]. The immunogenic HupB found in the cell wall fraction of active $M t b$ was described earlier in the literature [19]. It was also found that the concentration 
I

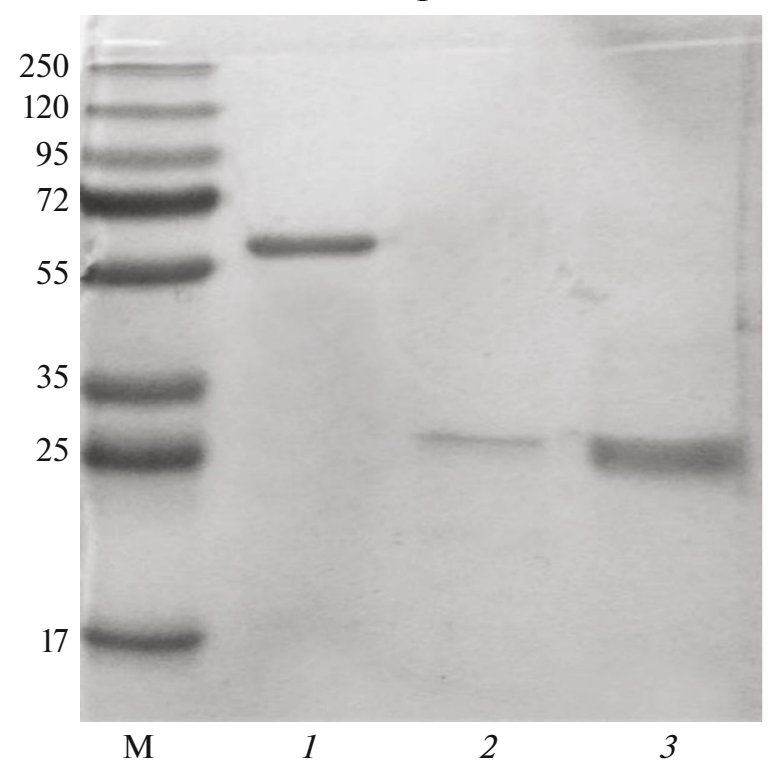

II

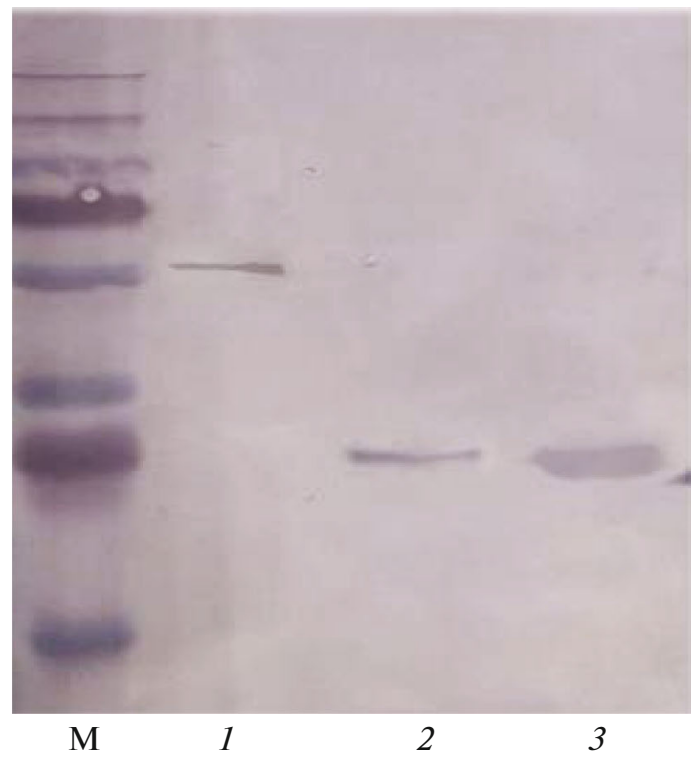

Fig. 2. SDS-electrophoresis in 12\% PAAG (I) of recombinant proteins (I) Rv0341 (1), Rv2018 (2), Rv1509 (3) and the corresponding immunoblot (II) with antibodies of pooled sera of TB patients.
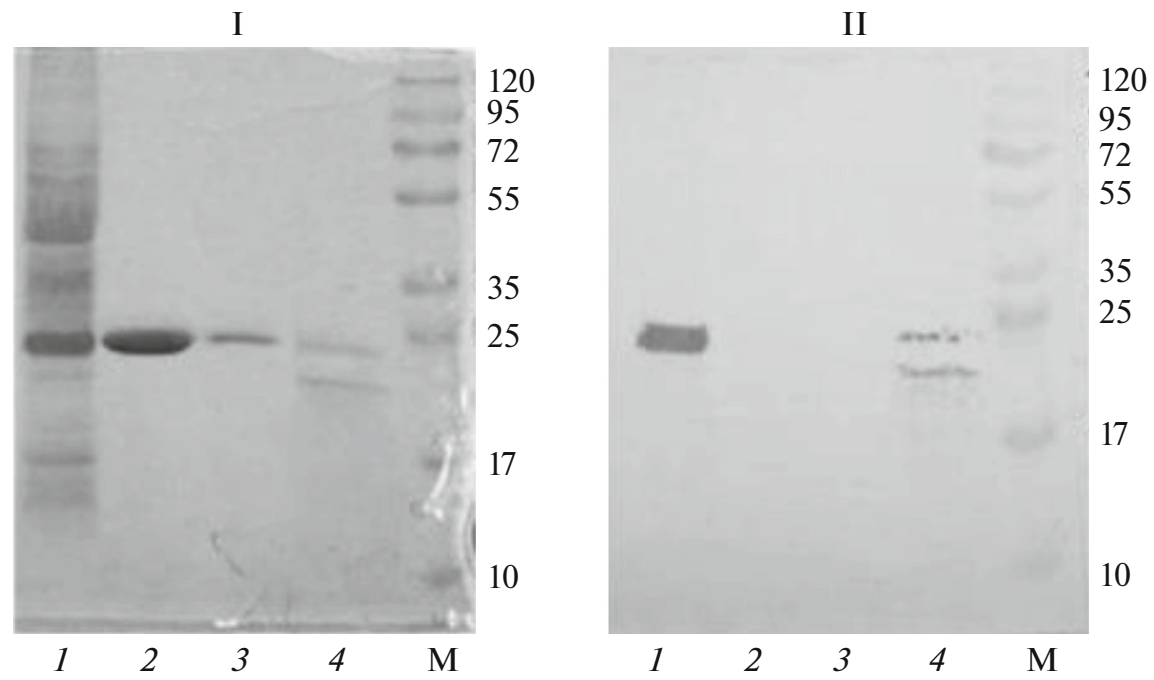

Fig. 3. SDS-electrophoresis in $12 \%$ PAAG of membrane extract of $M$. tuberculosis cells, three recombinant proteins, revealed in the immunoreactive band in membrane fraction (I) and the corresponding immunoblot (II) with pooled sera of TB patients: 1, SDS extract from membranes; 2, Rv3676; 3, Rv0432; 4, Rv2986.

of antibodies to this protein or HupB fragments in the sera of TB patients significantly exceeds that of healthy donors $[20,21]$. However, these data were not confirmed in studies of the total immunoproteome in active $M t b$ cells. Such studies evaluated the immunogenicity for most proteins of the $M t b$ proteome [13, 15]. For example, in a 2010 study [13] of the total pool of $M t b$ proteins, 484 proteins were found to be recognized by patient sera; they did not include the proteins identi- fied in our study (including HupB). Of the 484 proteins, the 13 proteins most often recognized by individual sera were isolated. However, the immunogenicity of proteins even in this group varied significantly among patients with TB. A similar large variability in immunogenicity was described in a recent publication on TB serodiagnosis in 755 patients from several countries with a panel of $22 \mathrm{Mtb}$ antigens preselected from the total proteome in the form of recombinant proteins 
(a)

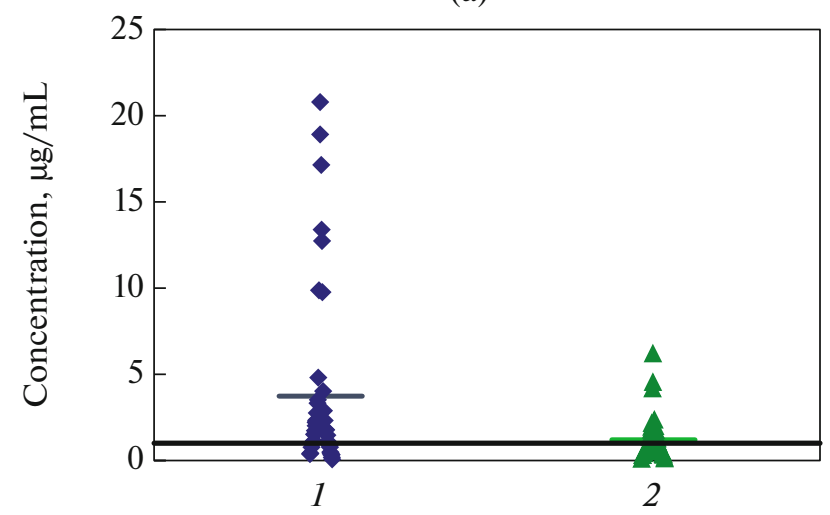

(c)

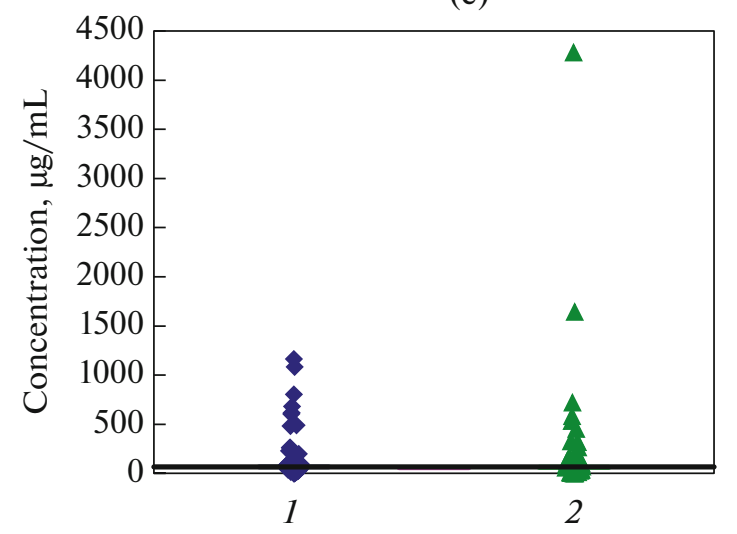

(b)

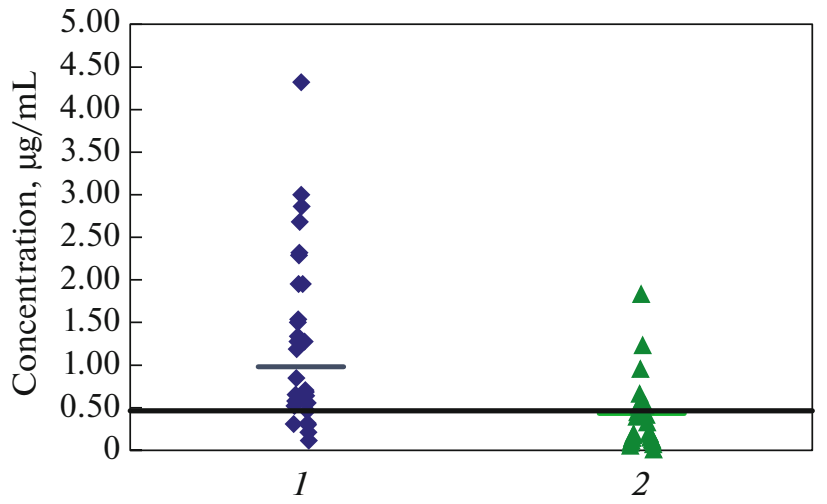

(d)

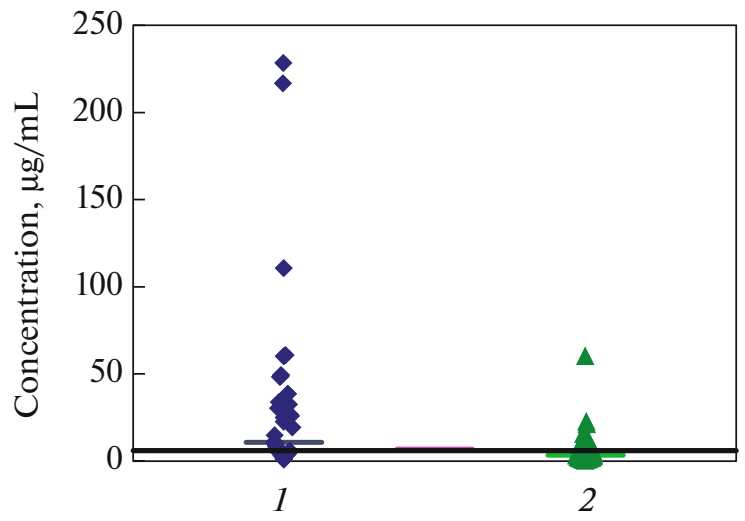

Fig. 4. ELISA binding of recombinant proteins Rv1509 (a), Rv0341 (b), Rv2018 (c), and Rv2986 (d) with antibodies of sera from individual TB patients (1) and healthy donors (2) (a total of 42 specimens from TB patients and 42 specimens of healthy donors were used).

[14], as well as in a work on the identification of biomarkers for the serodiagnosis of latent TB [22].

The fact that the antigens selected in our study were not found in the publications cited above may be due to the methods used to express a large number of proteins with special protein microarrays that do not cover $100 \%$ of the $M t b$ proteome [13], in which the purity of the expressed proteins is not achievable [14]. Such an approach differs from the expression of individual proteins, for which experimental selection was carried out and immunogenic proteins were identified with the use of in vitro models similar to the one used our study, which, hence, represents a promising direction.

In general, the use of this approach made it possible to identify immunodominant $M t b$ proteins, including novel ones not been previously described in the literature that demonstrate the ability to bind antibodies in the sera of TB patients. Since dormant $M t b$ cells were investigated in this study, it cannot be excluded that presence of antibodies in sera to the detected immunodominant proteins is associated with persistence of the Mtb pathogen in the host body.
In both the cited works and our study, the quantity of antibodies to individual antigens varies significantly in TB patients. It is thought that this may occur for several reasons, including (1) the occurrence of most pathogen cells in a different metabolic and physiological state in a particular patient and, hence, the different expression of a given antigen at the time of blood sampling; (2) the genetic characteristics of the patients and the associated features of the immunoresponse, which may also affect the synthesis of antibodies; and (3) the average, low level of humoral response in TB patients (especially in chronic infection), which leads to variability in the quantity of antibodies to a specific antigen $[13,14]$. Conversely, antibodies that react with the same antigens are detected in the sera of some healthy people. This may be due to the presence of nonspecific $M t b$ domains in the primary structure of the studied proteins. A study of the immunoreactivity of polypeptides constructed based on the specific protein domains revealed in this study may be promising in terms of TB serodiagnosis. 


\section{ACKNOWLEDGMENTS}

This study was conducted with the facilities of the Industrial Biotechnologies Center for Common Use (Bach Institute of Biochemistry, Fundamentals of Biotechnology Federal Research Center).

\section{FUNDING}

This study was supported by the Russian Science Fund (grant no. 16-15-00245-P). The Rv0341 recombinant protein was obtained with the support of the Russian Foundation for Basic Research, project no. 18-015-00239.

\section{COMPLIANCE WITH ETHICAL STANDARDS}

Conflict of Interests. The authors declare that they have no conflict of interest.

Statement of Compliance with Standards of Research Involving Humans as Subjects. All procedures performed in studies involving human participants were in accordance with the ethical standards of the institutional and/or national research committee and with the 1964 Helsinki Declaration and its later amendments or comparable ethical standards. Informed consent was obtained from all individual participants involved in the study.

\section{OPEN ACCESS}

This article is distributed under the terms of the Creative Commons Attribution 4.0 International Public License (http://creativecommons.org/licenses/by/4.0/), which permits unrestricted use, distribution, and reproduction in any medium provided you give appropriate credit to the original author(s) and the source, provide a link to the Creative Commons license, and indicate if changes were made.

\section{REFERENCES}

1. Nechaeva, O.B., Tuberk. Bolezni Legk., 2018, vol. 8, no. 96.

2. Apt, A.S., Logunova, N.N., and Kondratieva, T.K., Tuberculosis, 2017, vol. 106, pp. 1-8.

3. Shleeva, M.O., Kudykina, Y.K., Vostroknutova, G.N., Suzina, N.E., Mulyukin, A.L., and Kaprelyants, A.S., Tuberculosis, 2011, vol. 91, no. 2, pp. 146-154.

4. Trutneva, K.A., Shleeva, M.O., Demina, G.R., Vostroknutova, G.N., and Kaprelyans, A.S., Front. Cell. Infect. Microbiol., 2020, vol. 10, p. 26.

5. Connell, N.D., Methods Cell Biol., 1994, vol. 45, pp. 107-125.

6. O'Farrell, P.H., J. Biol. Chem., 1975, vol. 250, pp. 4007-4021.

7. Flores, R., Anal. Biochem., 1978, vol. 88, pp. 605-611.
8. Welin, A., Raffetseder, J., Eklund, D., Stendahl, O., and Lerm, M., J. Innate Immun., 2011, vol. 3, no. 5, pp. 508-518.

9. Barer, M.R. and Harwood, C.R., Adv. Microb. Physiol., 1999, vol. 41, pp. 93-137.

10. Shleeva, M., Trutneva, K., Shumkov, M., Demina, G., and Kaprelyants, A., FEBS Open Bio, 2018, vol. 8, no. S1, p. 400.

11. Flyer, D.C., Ramakrishna, V., Miller, C., Myers, H., McDaniel, M., Root, K., Flournoy, C., Engelhard, V.H., Canaday, D.H., Marto, J.A., Ross, M.M., Hunt, D.F., Shabanowitz, J., and White, F.M., Infect. Immun., 2002, vol. 70, no. 6, pp. 2926-2932.

12. Bettencourt, P., Muller, J., Nicastri, A., Cantillon, D., Madhavan, M., Charles, P.D., Fotso, C.B., Wittenberg, R., Bull, N., Pinpathomrat, N., Waddell, S.J., Stylianou, E., Hill, A., Ternette, N., and McShane, H., NPJ Vaccines, Springer US, 2020, vol. 5, no. 2. https://doi.org/10.1038/s41541-019-0148-y

13. Kunnath-Velayudhan, S., Salamon, H., Wang, H.Y., Davidow, A.L., Molina, D.M., Huynh, V.T., Cirillo, D.M., Michel, G., Talbot, E.A., Perkins, M.D., Felgner, P.L., Liang, X., and Gennaro, M.L., Proc. Natl. Acad. Sci. U. S. A., 2010, vol. 107, no. 33, pp. 14703-14708.

14. Broger, T., Basu, RoyR., Filomena, A., Greef, C.H., Rimmele, S., Havumaki, J., Danks, D., SchneiderhanMarra, N., Gray, C.M., Singh, M., Rosenkrands, I., Andersen, P., Husar, G.M., Joos, T.O., Gennaro, M.L., Lochhead, M.J., Denkinger, C.M., and Perkins, M.D., Clin. Infect. Dis., vol. 64, no. 7, pp. 947-955.

15. Peng, Z., Chen, L., and Zhang, H., J. Int. Med. Res., 2020, vol. 48 , no. 3 . https://doi.org/10.1177/0300060520910042

16. Matsumoto, S., Furugen, M., Yukitake, H., and Yamada, T., FEMS Microbiol. Lett., 2000, vol. 182, no. 2, pp. 297-301.

17. Matsumoto, S., Yukitake, H., Furugen, M., Matsuo, T., Mineta, T., and Yamada, T., Microbiol. Immunol., 1999, vol. 43, no. 11, pp. 1027-1036.

18. Lewin, A., Baus, D., Kamal, E., Bon, F., Kunisch, R., Maurischat, S., Adonopoulou, M., and Eich, K., BMC Microbiol., 2008, vol. 8, p. 91.

19. Yeruva, V.C., Duggirala, S., Lakshmi, V., Kolarich, D., Altmann, F., and Sritharan, M., Clin. Vaccine Immunol., 2006, vol. 13, no. 10, pp. 1137-1142.

20. Sritharan, N., Choudhury, M., Sivakolundu, S., Chaurasia, R., Chouhan, N., Rao, P.P., and Sritharan, M., Eur. J. Clin. Microbiol. Infect. Dis., 2014, vol. 34, no. 1, pp. 33-40.

21. Sivakolundu, S., Mannela, U.D., Jain, S., Srikantam, A., Peri, S., Pandey, S.D., and Sritharan, M., Trans $R$ Soc. Trop. Med. Hyg, 2013, vol. 107, no. 1, pp. 43-50.

22. Zhou, F., Xu, X., Wu, S., Cui, X., and Pan, W., BMC Infect. Dis., 2017, vol. 17, no. 1, p. 793.

Translated by M. Novikova 